\title{
NECTIN4 Promotes Papillary Thyroid Cancer Cell Proliferation, Migration, and Invasion and Triggers EMT by Activating AKT [Corrigendum]
}

Hao RT, Zheng C, Wu CY, et al. Cancer Manag Res. 2019;11:2565-2578.

Upon reviewing the article, the authors noticed an error in the last fund number in the acknowledgments section on page 2577. The fund number (Y20170030) was found to be incorrectly entered. The correct number is Y20180855. The authors apologize for this error.

\section{Publish your work in this journal}

Cancer Management and Research is an international, peer-reviewed open access journal focusing on cancer research and the optimal use of preventative and integrated treatment interventions to achieve improved outcomes, enhanced survival and quality of life for the cancer patient.
The manuscript management system is completely online and includes a very quick and fair peer-review system, which is all easy to use. Visit http://www.dovepress.com/testimonials.php to read real quotes from published authors. 